\title{
Considerations Related to Safe Handling of Dead Bodies of Deceased Persons with COVID-19: Issues and Review of Guidelines
}

\author{
Vaibhav Anjankar ${ }^{1}$, Ashish Anjankar², Anil J. Anjankar ${ }^{3}$ \\ ${ }^{1}$ Associate Professor of Anatomy, ${ }^{2}$ Associate Professor of Biochemistry, ${ }^{3}$ Professor of Forensic Medicine \& \\ Toxicology, Jawaharlal Nehru Medical College, Datta Meghe Institute of Medical Sciences (DMIMS)
}

\begin{abstract}
The Novel Corona Virus (COVID-19) earlier known only as the Wuhan virus, expanded its circle and finally spreading its routes to India. The guidelines/considerations published by various government organizations for management of dead bodies in context of COVID-19 were reviewed.

The problem arrived when experts found some loopholes in government guidelines and other social issues were raised in different parts of country regarding the final rituals of deceased died due to suspected or confirmed cases of COVID-19. Some cases were also observed in neighboring countries also.

In this article, light was thrown on utility of body bags for handling dead bodies, environmental cleaning, autopsy \& embalming related issues, precautions in case of community deaths etc. We tried to discuss the issues in light of available guidelines by government of India and other international guidelines.
\end{abstract}

Keywords: COVID-19, cremation, decontamination, funeral, decomposition.

\section{Introduction}

Some of the recent viral outbreaks showing the involvement of respiratory system include severe acute respiratory syndrome (SARS) ${ }^{1}$ in 2002-03, Middle-East respiratory syndrome (MERS) ${ }^{2}$ in 2012 etc that lead to life threatening illness. In December 2019, the world was introduced to a novel coronavirus severe acute respiratory syndrome coronavirus 2 (SARS-CoV-2; formerly called 2019-nCoV) causing coronavirus disease 2019 (COVID-19) ${ }^{3}$ after the outbreak of pneumonia in Wuhan, a city in Hubei Province of China ${ }^{4}$. The Novel Corona Virus (COVID-19) earlier known only as the Wuhan virus, expanded its circle and finally spreading its

\section{Corresponding Author:}

Dr. Vaibhav Anjankar

Jawaharlal Nehru Medical College, Datta Meghe

Institute of Medical Sciences (DMIMS), Sawangi

(Meghe), Wardha, Maharashtra, India-442107

Mobile: 9422856368

e-mail: vaibhav_anjankar@yahoo.co.in routes to India ${ }^{5}$. The first case of COVID-19 in India was reported on 30 January 2020 originating from China ${ }^{5}$. The World Health Organisation (WHO) declared the COVID-19 outbreak a Global Health Emergency on January $30,2020^{3}$, and pandemic on 11 March $2020^{3}$. As per the data provided by Ministry of Health and Family welfare, Govt. of India, till 19 May 2020, in India ${ }^{6}$ total active cases are 77103 , cured or discharged patients and death toll reaching to 402 .

COVID-19 pandemic have crossed the death records all over the world including European countries whose health system is considered one of the best in the world. Even the superpower America is struggling to curb the death rate. India being densely populated, the risk of spread is more. The guidelines/considerations of various government organizations for management of dead bodies in context of COVID-19 were reviewed. Certain issues published in media regarding dead body management due to COVID-19 are also discussed.

Present available guidelines for safe disposal of dead bodies: Various organizations/government bodies 
have put forward their respective guidelines for safe management of a dead body in the context of COVID-19. Some of the major guidelines across the globe available for the same purpose are mentioned below.

- 'COVID-19: Guidelines on Dead Body Management'- by Director General of Health Services (DGHS), $\mathrm{MOH} \& \mathrm{FW}, \mathrm{GoI}^{7}$ published on 15.03.2020

- 'Infection Prevention and Control for the safe management of a dead body in the context of COVID-19' by World Health Organization (WHO) ${ }^{8}$ - Interim guidelines published on 24.03.2020

- 'Considerations related to the safe handling of bodies of deceased persons with suspected or confirmed COVID-19' by European Centre for Disease Prevention and Control (ECDC) ${ }^{9}$, Stockholm.

- 'Dead body management in the context of the novel coronavirus (COVID-19)' by Pan American Health Organization $(\mathrm{PAHO}){ }^{10}$ - Interim recommendations published on 18.03.2020

- 'COVID-19 - Handling of bodies by funeral directors' by State of New South Wales NSW Ministry of Health, Govt. of Australia ${ }^{11}$ published on 02.04 .2020

- 'Disposal of dead bodies of Covid-19' by Municipal Commissioner, Municipal Corporation of Greater Mumbai $^{12}$ released on 30.03.2020

The Concern: In spite of above mentioned available guidelines, some issues were observed.

1. Lacunae in guidelines: Anadolu Agency report ${ }^{13}$ mention about experts' belief that Health Ministry's guidelines regarding the handling of infected dead bodies have huge gaps. The seven-page guidelines issued by the Health Ministry do not specify the method of cremation or the plastering of graves ${ }^{13}$. No clear guidelines are written in report about the body bags used.

2. Social issues: The controversies were published in certain media reports about cremation of lady in Delhi who died after corona virus infection following co-morbidity. The staff from Delhi's two crematoriums allegedly denied last rites, fearing the spread of virus ${ }^{14,15}$. Similar news came from Mumbai where cemetery at Malad denied burial of dead body of corona victim, fearing spread of coronavirus ${ }^{16}$.
The road blockade and protest was observed by local residents of Nimtala of Kolkata preventing government officials from cremating dead body of corona virus infected patient ${ }^{17}$. The report of 'OutLook India' also mention that the body was embalmed with chemicals contrasting to $\mathrm{MOH} \&$ FW guidelines which says embalming should be avaoided $^{17,7}$.

3. A heartbreaking tragedy published in The HinduChennai, where an orthopedic surgeon of Nellore died due to COVID-19 after contracting infection from his patients. The local residents, ignoring prohibitory orders, protested the cremation of a doctor with apprehension that the cremation of the body could result in the spread of novel Coronavirus in the area ${ }^{18}$.

Before handling the dead body: The most important task is to impart training of persons involved in handling the dead body. This include: ${ }^{7,8,11}$

- infection control procedures

- hand hygiene

- how to put on and remove personal protective equipments (PPE)

- $\quad$ safe handling of sharps

- regular environmental decontamination including all surfaces and equipments with disinfectant ${ }^{11}$

- disinfect the bag housing dead body; instruments and devices used on the patient ${ }^{7}$

- ensure that any body fluids leaking from orifices are contained $^{8}$

- avoid unnecessary manipulation of the body that may expel air from the lungs ${ }^{11}$

Utility of Body bags: $\mathrm{WHO}^{8}$ guidelines say that body bags are not necessary, although they may be used for other reasons (excessive fluid leakage) and further it is mentioned to wrap the body in cloth. Interim recommendations of $\mathrm{PAHO}^{10}$ also recommend that body bags are not necessary for packing the body. But factsheet issued by NSW, Australia ${ }^{11}$ writes that body should be transported and stored in a two leak proof body bags (double bagged). The outer body bag should be clearly and permanently labeled, such as: "COVID-19 - Handle with care". Used body bags should be disposed of in clinical waste streams ${ }^{11}$. MOH \& FW guidelines ${ }^{7}$ mentions about using of leak proof plastic body bag but 
thickness is not mentioned. Precautions issued by dept. of health, Govt. of Hong Kong ${ }^{20}$ recommend robust and leak-proof transparent plastic bag of not less than 150 $\mu \mathrm{m}$ thick, and should accompany with another layer of a mortuary sheet or opaque bag. It should be zippered closed; Pins are not to be used ${ }^{20}$. Dr. T. Jacob John, a former head of the Virology Centre at ICMR said the plastic bag covering the body should be at least 100 microns thick, so it does not tear off easily ${ }^{13}$.

\section{Environmental Cleaning: Environmental} Cleaning is the key stone procedure to curtail the spread of infection. It should be part of Standard Precautions, which should be applied to all patients in all healthcare facilities

MOH \& FW guidelines ${ }^{7}$ quoted to wipe all surfaces with $1 \%$ Sodium Hypochlorite solution with contact time of 30 minutes and then allowed to air dry. Hospital Infection Control Committee of AIIMS, New Delhi ${ }^{21}$ advocated the use of freshly prepared $1 \%$ Sodium Hypochlorite for a contact time of at least 10 minutes as a disinfectant for cleaning and disinfection. Alcohol (e.g. isopropyl $70 \%$ or ethyl alcohol $70 \%$ ) can be used to wipe down surfaces where the use of bleach is not suitable, e.g. metals. JIPMER ${ }^{22}$ recommended use of $0.5 \%$ Hypochlorite with contact time of 10 minutes.

WHO- Interim Guidelines recommended disinfectant with a minimum concentration of $0.1 \%$ (1000 ppm) sodium hypochlorite (bleach), or 70\% ethanol for at least 1 minute. $\mathrm{PAHO}^{10}$ advised surface disinfection with $0.1 \%$ sodium hypochlorite or $62-71 \%$ ethanol. ECDC ${ }^{9}$ mentioned use of hospital disinfectants active against viruses. Decontamination may be performed with $0.1 \%$ sodium hypochlorite.

Autopsy related guidelines: $\mathrm{MOH} \& \mathrm{FW}$ guidelines ${ }^{7}$ clearly mention to avoid autopsy. If autopsy is to be performed for special reasons, infection prevention and control practices should be adopted. The lungs and other organs may still contain live virus and additional respiratory protection is needed during aerosol generating procedures like use of power saws, washing of intestines etc ${ }^{8}$. Airborne precautions include fluid resistant \& long sleeved gown, P2/N95 masks, face shields or safety glasses etc ${ }^{11}$. Number of staffs should be kept to minimum; round ended scissors \& appropriate PPE should be used ${ }^{8}$. Only one body cavity should be opened at a time ${ }^{7}$. Negative pressure should be maintained in mortuary. Mortuary should be adequately ventilated $^{10}$.
After autopsy, body must be disinfected with $1 \%$ Sodium Hypochlorite and covered by a body bag. The exterior of body should also be decontaminated with $1 \%$ Sodium Hypochlorite solution.

DMER, Mumbai issued medical guidelines ${ }^{23}$ for death declaration on 09 April 2020 which mentions about no postmortem examination in suspected COVID-19 deaths.

Embalming: All major guidelines ${ }^{7,8,11}$ mentions that embalming should not be performed on dead bodies of COVID-19. This minimizes excessive manipulation of body ${ }^{8}$. If embalming is must, embalmer should be certified and trained in the use of PPE for contact and airborne precautions. This includes $\mathrm{P} 2 / \mathrm{N} 95$ respirator which has been fit checked, gown, gloves and eye protection $^{11}$.

Community Deaths: The present guidelines of $\mathrm{MOH} \& \mathrm{FW}^{7}$ are limited to hospital deaths only. $\mathrm{MOH}$ \& FW guidelines ${ }^{7}$ lack the guidelines for such home deaths. Interim guidelines of $\mathrm{WHO}^{8}$ mention about these.

- Staff that will manage dead bodies, such as ambulance staff, police and general practitioners, should use PPE compulsorily9.

- Person preparing dead body for last rites (e.g. washing, cleaning or dressing body, tidying hair, trimming nails or shaving) should wear gloves, eye and mouth protection (face shield or goggles and medical mask). Clothing worn to prepare the body should be immediately removed and washed after the procedure or an apron or gown should be worn. Washing of hands with soap and water is to be followed ${ }^{8}$.

- Children, elderly people ( $>60$ years old), and anyone with underlying illnesses should not be involved. Number of people involved in preparations should be kept to minimum ${ }^{8}$.

- Nobody should touch/kiss the body and should wash their hands thoroughly with soap and water or alcohol based hand rub to minimize the risk of transmission ${ }^{11}$; physical distancing measures should be strictly applied (at least 1 meter between people) ${ }^{8}$.

- Those involved with placing the body in the grave, on the funeral pyre, etc. should wear gloves and wash hands with soap and water. 
- Funeral should not involve more than five people ${ }^{12}$. Participants should observe social distancing plus respiratory etiquettes and hand hygiene ${ }^{8}$.

- No need to burn or dispose of the belongings (cloths, utensils etc) of the deceased. However, they should be handled with gloves and cleaned with a detergent followed by disinfection with a solution of at least $70 \%$ ethanol or $0.1 \%$ (1000 ppm) bleach ${ }^{8}$.

Transportation: WHO guidelines mention that no special transport equipment or vehicle is required ${ }^{8}$. Standard precautions (surgical mask, gloves, etc) must be followed by the personnel handling the body ${ }^{7}$ to minimize exposure to infected bodily fluids, contaminated objects and other contaminated environmental surfaces ${ }^{9}$

The body, secured in a body bag, exterior of which is decontaminated poses no additional risk to the staff involved in dead body transportation ${ }^{7}$. During transport, direct contact with human remains or bodily fluids should be avoided ${ }^{9}$. The vehicle should be decontaminated with $1 \%$ Sodium Hypochlorite ${ }^{7}$ after transportation.

Cremation or Burial: WHO interim guidelines ${ }^{8}$ clearly mention that people who died from COVID-19 can be buried or cremated. $\mathrm{MOH} \& \mathrm{FW}$ guidelines ${ }^{7}$ and PAHO recommendations ${ }^{10}$ also mention about the both.

In another instance, directions issued by Municipal Commissioner of Municipal Corporation of Greater Mumbai on 30.03.2020 quoted that all dead bodies of COVID-19 should be cremated at the nearest crematorium irrespective of religion. The reason being existing burial grounds are in highly dense locality with high chances of contamination. Further burial should not be allowed ${ }^{12}$ as procedure of packing the body in plastic bag and burying same prevent early decomposition and risk continuing the virus for future spread. The same circular was then revised and the BMC has allowed burial within Mumbai provided the burial ground is large enough to ensure there is no threat of transmission to the area's residents ${ }^{19}$.

Department of Forensic Medicine at the AIIMS, New Delhi has released its specific protocol, mentioning about points missed in the guidelines issued by the Health Ministry ${ }^{13}$. Head of Forensic Medicine dept of AIIMS New Delhi also clarified that cremation of dead body of person died due to corona virus has no side effects by any method using fire or electrical or gas or by burial ${ }^{13}$.
New protocol described that cremation should be preferred for the complete elimination of chances of infection in either electric or gas crematorium in a zipped body bag. If the burial of the body is requested, then it should be assured that the body is buried in a thick, airtight coffin ${ }^{13}$. Dead body needs to be buried at a depth of 4-6 feet and should be cemented immediately as an additional precautionary measure ${ }^{13}$.

Director AIIMS New Delhi, Dr. Guleria clarified that corona virus can not spread through dead bodies. It spread from respiratory secretions. Coughing is necessary for spread of virus. So there is no risk in cremating the infected dead bodies ${ }^{15}$.

\section{Conclusion}

Considering the huge impact caused by COVID-19 pandemics on Global health care systems, it is important to reduce its transmission and prevent the number of deaths. It can spread through nasopharyngeal secretions but care should also be taken while contacting body fluids of deceased persons of suspected or confirmed case of COVID-19.

Guidelines issued by various government authorities should be meticulously followed and utmost care should be taken while handling the dead body by the concerned.

\section{Conflict of Interest: Nil}

\section{Sources of Funding: Self funded}

\section{Ethical Clearance: Not needed}

\section{References}

1. Centers for Disease Control and Prevention. Frequently asked questions about SARS [Online]. [cited on 2020 May 25] Available from: URL: https://www.cdc.gov/sars/about/faq.html

2. World Health Organization. Middle East respiratory syndrome corona virus (MERS-CoV). 2019. [cited on 2020 May 25] Available from: URL: https:// www.who.int/emergencies/mers-cov/en.

3. Rahman S and Bahar T. COVID-19: The New Threat. Int J Infect. 2020; 7(1):e102184.

4. CDC. Novel coronavirus, Wuhan, China. 2019. [Online] [cited 2020 May 25]. Available from: https:/www.cdc.gov/coronavirus/2019-ncov/ about/index.html.

5. Kachroo V. Novel coronavirus (COVID-19) in 
India: current scenario. International Journal of Research and Review. 2020; 7(3): 435-47.

6. Ministry of Health and Family Welfare.[Online] [cited on 2020 May 25] Available at: URL: https:// www.mohfw.gov.in/

7. COVID-19: Guidelines on Dead Body Management by Government. Director General of Health Services (DGHS), Ministry of Health and Family Welfare (MOHFW), Govt. of India. 15.03.2020. [Online] [cited on 2020 May 25] Available at: URL: https://www.mohfw.gov.in/pdf/1584423700568 COVID19GuidelinesonDeadbodymanagement.pdf

8. World Health Organization. (2020). Interim guidance on Infection Prevention and Control for the safe management of a dead body in the context of COVID-19. 24.03.2020. [Online] [cited on 2020 May 25] Available at : URL: https://apps.who. int/iris/bitstream/handle/10665/331538/WHOCOVID-19-IPC_DBMgmt-2020.1-eng.pdf

9. European Centre for Disease Prevention and Control (ECDC). (2020). Considerations related to the safe handling of bodies of deceased persons with suspected or confirmed COVID-19. Stockholm. ECDC: 2020. [Online] [cited on 2020 May 25] Available at: URL: https://www.ecdc. europa.eu/sites/default/files/documents/COVID19-safe-handling-of-bodies-or-persons-dyingfrom-COVID19.pdf

10. 'Dead body management in the context of the novel coronavirus (COVID-19)' by Pan American Health Organization (PAHO). 18.03.2020. [Online] [cited on 2020 May 25] Available at: URL: https://www. paho.org/en/documents/dead-body-managementcontext-novel-coronavirus-covid-19

11. 'COVID-19 - Handling of bodies by funeral directors' by State of New South Wales NSW Ministry of Health, New South Wales. Australia. 02.04.2020. [Online] [cited on 2020 May 25] Available at: URL: https://www.health.nsw.gov. au/Infectious/factsheets/Pages/covid-19-funeraldirectors.aspx

12. 'Disposal of dead bodies of Covid-19' by Municipal Commissioner, Municipal Corporation of Greater Mumbai. No. MGC/A/2942 dated 30.03.2020

13. COVID-19 in India: Mishandling infected dead bodies spell anxiety. [Online] [cited on 2020 May 25] Available at: URL: https://www.aa.com.tr/ en/asia-pacific/covid-19-in-india-mishandling- infected-dead-bodies-spell-anxiety-/1778602

14. No, Dead Bodies Don't Spread Coronavirus: AIIMS Clears Air After Cremation Controversy. Medical Dialogues. 16 March 2020. [Online] [cited on 2020 May 25] Available at: URL: https:// medicaldialogues.in/news/health/no-dead-bodiesdont-spread-coronavirus-aiims-clears-air-aftercremation-controversy-63961

15. Nothing to worry in cremating COVID-19 victims, clarify doctors after Delhi woman denied cremation. ANI News. 14 March 2020. [Online] [cited on 2020 May 25] Available at: URL: https://www.aninews.in/news/national/generalnews/nothing-to-worry-in-cremating-covid-19victims-clarify-doctors-after-delhi-woman-deniedcremation20200314235842/

16. Refused burial by Malad kabrastan, Muslim Covid-19 victim cremated. Times of India. 03 April 2020. [Online] [cited on 2020 May 25] Available at: URL: https://timesofindia.indiatimes. $\mathrm{com} / \mathrm{city} / \mathrm{mumbai} /$ refused-burial-by-maladkabrastan-muslim-covid-19-victim-cremated/ articleshow/74958344.cms

17. Locals Protest against Cremation of Coronavirus Patient In West Bengal Amid Fears of Contamination. Outlook. 10 April 2020. [Online] [cited on 2020 May 25] Available at: URL: https://www.outlookindia.com/website/story/ india-news-locals-protest-against-cremation-ofcoronavirus-patient-in-west-bengal-amid-fears-ofcontamination/349332

18. Local residents protest cremation of doctor's body in Chennai. The Hindu. 13 April 2020. [Online] [cited on 2020 May 25] Available at URL https:// www.thehindu.com/news/cities/chennai/localresidents-protest-cremation-of-doctors-body-inchennai/article31331307.ece

19. BMC withdraws circular on burial of infected bodies. The Hindu. Mumbai, March 31, 2020. [Online] [cited on 2020 May 25] Available at: URL: https://www.thehindu.com/news/cities/ mumbai/bmc-withdraws-circular-on-burial-ofinfected-bodies/article31212732.ece

20. 'Precautions for Handling and Disposal of Dead Bodies' issued by Center for Health Protection, Department of Health, Govt of Hong Kong, Special Administrative Region. [Online] [cited on 2020 May 25] Available at: URL: https://www.chp.gov. hk/files/pdf/grp-guideline-hp-ic-precautions_for_ 
handling_and_disposal_of_dead_bodies_en.pdf

21. Hospital Infection Control Committee AIIMS, New Delhi. Infection Prevention \& Control Guidelines for 2019-nCoV (COVID-19). (2020). [Online] [cited on 2020 May 25] Available at URL: https:// www.aiims.edu/images/pdf/notice/hosp.admn-9-320.pdf

22. Hospital Infection Control Committee, JIPMER, Version 1. 24/03/2020. COVID-19: Infection
Prevention \& Control Standard Operating Procedure.

23. Medical guidelines for death declaration and procedural method in diagnosed suspected COVID-19 cases, brought dead cases, unknown and unclaimed the bodies, and inuest procedures. Directorate of Medical Educaton \& Research (DMER). DMER/DeathCertification/noPM/ Covid-39/35/2020 dated 09.04.2020. 